\title{
Views of Teachers Working in South-East Anatolia Region Regarding Current Problems in Education
}

\author{
Birsen Bagceci ${ }^{1}$ \\ ${ }^{1}$ Faculty of Education, Gaziantep University, Gaziantep, Turkey \\ Correspondence: Birsen Bagceci, Faculty of Education, Gaziantep University, B Blok 219, Gaziantep, Turkey. \\ Tel: 90-532-678-2995. E-mail: bagceci@gantep.edu.tr
}

Received: January 24, 2017

Accepted: March 9, 2017

Online Published: March 23, 2017

doi:10.5539/jel.v6n3p94

URL: http://doi.org/10.5539/jel.v6n3p94

\begin{abstract}
The purpose of this study is to identify the current problems of the teachers working in the provinces of Southeastern Anatolia in Turkey and to list these problems according to their importance. Screening model is used in the study. One open-ended question was asked (identify seven problems related to the education system and order them according to their importance) to 270 teachers working in Gaziantep, Shanlıurfa, Diyarbakır, Kahramanmaraş, Mardin, Şırnak and Adıyaman (Southeastern provinces of Turkey). The collected data were analyzed using quantitative research method. Descriptive and chi-square analysis was conducted to create categories and to determine whether there is a significant difference between the gender, seniority and class-branch. Education problems were classified into six categories: Problems related with 1) School's physical conditions; 2) Teachers; 3) Education system; 4) Educational management, inspection, planning and economy; 5) Education Programs and training; 6) Students-parents. There is no significant difference between these categories expressed by the teachers. There is also no significant difference among the first seven most expressed problems according to gender, class-branch, and teachers' seniority.
\end{abstract}

Keywords: educational problems, regional educational problems, teacher training

\section{Introduction}

Turkey has a huge education system approaching 26 million students and more than 800,000 teachers. Therefore, the education system has many problems due to such a large system. The main problems of this education system are listed as follows; Information and communication technologies, the problems of education workers, inequalities in education access, rote learning, physical infrastructure problems, transitions between stages, educational programs, the lack of professionalism of school administrations, financial problems of schools, schooling rates, problems with teaching, private teaching institutions, problems with teachers training, decentralized management, political policies, continuous changes in the education system, crowded classrooms, vocational technical education and examination system (Aşkar, 2007; Arslan, 2004; Balc1, 2004; Eğitim Sen, 2009a; Yaman, 2006-2010; Gülbahar \& Güven, 2008; ERG, 2008b; MEB, 2005; Eraslan, 2009; ERG, 2010; Yolcu \& Kartal, 2010).

Education monitoring report performed in 2011 by Educational Reform Initiative ERG (2012) indicated the current issues of education. These problems can be related to the system resulting changes and uncertainities, there are the some examples; the lack of education strategy, the change of starting age of elementary education with 4+4+4 regulation (Karadeniz, 2012) (four years primary school, four years secondary school and four years high school as total twelve years compulsory education), converting the elementary schools into primary and secondary schools, establishment of school types in secondary school level, what will be the curriculum and elective courses, making secondary education obligatory. In addition, there are also different problems such as; insufficient allocated budget for the reforms, the inadequacy of the infrastructure for Fatih Project, the inability to reach the desired targets in pre-school education, gender and provincial inequalities in the access of secondary schools. Moreover; according to ERG data (2012), difficulties in teacher training policies, newly appointed teachers are less experienced and they grow up in the city life, cause to be absenteeism of these teachers and to fail to go to Eastern or Southeastern Region and in-service training given to teachers cannot be achieved as desired before. 
The problems of teachers, which mentioned in the Parliamentary Research Report of the Grand National Assembly of Turkey, were summarized under six headings:

1) Problems in the teacher training system,

2) Problems of teachers' employment,

3) Problems related to the in-service and on-the-job training of teachers,

4) Problems related to educational environment where the teachers are working,

5) Problems related to teachers' personal rights,

6) Problems related to teachers' social status (Çalık, Türker, \& Çalık, 2011).

It is known that the problems identified by the parliamentary studies are continuously increasing.

In SETA's (2014) education workshop, the problems that should be solved and should be considered in education such as; the subject of the curriculum and the textbooks and content analysis; there are problems in teachers training, it is believed that Teacher Content Knowledge Examination (ÖABS), first implemented in 2013 , is a good practice but there are some deficiencies with this examination; teacher training strategy document should be prepared as soon as possible; Ministry of Education (MEB) and necessary institutions should take measures in order to reduce the teacher circulation which is shown among the reasons of failure in the East and Southeast; secondary school transitional exam requirements must be resolved and the process of closing the private teaching institutions.

MEB (2009) determined its weaknesses in the SWOT analysis of 2010-2014 strategic plan and these weaknesses can be listed as follows: crowded classrooms, double shift schooling, merged classes, the failure to establish the supply demand balance in teacher training and employment, rapid teacher changes in some regions, short-term education planning and frequent changes, unequal physical conditions of classes across Turkey, inadequate guidance services, lack of performance-based monitoring and evaluation, insufficient budget. The threat part in the same plan; regional socio-economic differences, the youths who are in compulsory education period, cannot be able to benefit from education services resulting from these youths are employed as seasonal workers, using the technology outside its purposes are also indicated among the problems.

In the 18th National Education Council, in order to solve the problems in education, the precautions were indicated as follows; structuring teacher training and employment system, promoting the financial situation and status of teachers, improving the physical conditions of the schools and reducing the population of the classrooms (MEB, 2010).

Despite the definition of "a specialization profession that takes the administrative tasks related to education, training and related management" 1739 National Education Law in Article 43 for the teaching profession, instead of raising qualified teachers which is one of the problems of education, many of people who do not have teaching profession knowledge have been nominated as a teacher with the thought of "if someone knows anything" then they can be teacher (Küçükahmet, 1999). In 2014, it is still possible that the people, who graduated from faculty of science and literature, still can be a teacher by providing them a formation. According to Akyüz (2012), the qualification of a teacher has not been paid enough attention and as a result education and training has been negatively affected and reputation of teaching profession did not get anywhere in the society.

As being a sacred profession, teaching needs to be socially and economically strengthened. When the value of the profession in society is considered to be related to the wage, teachers are not in a position to deserve the wages among the government officials. According to Demir and Ar1 (2013), the inadequacy of teachers' wages is expressed in various congresses and symposiums, but no positive developments are observed. In the study, which is conducted by Fidan and Fidecioğlu (2010), 57\% of 203 teachers indicate that they are negatively affected by the insufficient salary.

Educational interventions by governments, which are one of the educational problems, are observed in each period. Educational policies are applied according to the political views of the governments. There is no educational policy applied above the parties (Gedikoğlu, 2005). One of the indicators of the absence of a long-term education policy in Turkey is the change of 76 ministers of education in 93 years and the average duration of ministerial tasks is 1.2 year.

With the amendment in 2012, the compulsory education period in Turkey was increased to 12 years. As the change with twelve years compulsory education, a primary school became four years, a secondary school became four years and a high school became four years. This change brought new problems because the change 
was performed without any infrastructural preparations. The fact that, 60-80 months old children are in the same classes, there are crowded classes as a result of not having enough classrooms, the lack of necessary in-service training of teachers can be listed among the problems (Demirezen, 2012; Aykaç, Kabaran, Atar, \& Bilgin, 2014). The physical and equipmental deficiencies in schools increasingly continue as a result of the compulsory education becoming 12 years.

As seen below in Table 1, there is inequality of opportunity in education in Turkey. The rate of literacy in the countryside falls in half compared to the city (DİE, 2000). Moreover, the quality of education falls and the number of students per teacher is doubled on the outskirts of cities. This problem is especially evident in the schools in the East and Southeast regions. The number of students per teacher is 26 in Turkey, while it reaches 57 in Southeastern Anatolia (Şırnak) (YKKED, 2007).

Table 1. Regional educational data base

\begin{tabular}{lcccccc}
\hline Region & $\begin{array}{c}\text { Literacy } \\
\text { rate }\end{array}$ & $\begin{array}{c}\text { Female } \\
\text { literacy } \\
\text { rate }\end{array}$ & $\begin{array}{c}\text { Percentage of } \\
\text { university } \\
\text { graduates over } \\
\text { age 22 }\end{array}$ & $\begin{array}{c}\text { Schooling } \\
\text { rate in } \\
\text { primary } \\
\text { school }\end{array}$ & $\begin{array}{c}\text { Schooling } \\
\text { rate in high } \\
\text { school }\end{array}$ & $\begin{array}{c}\text { Schooling rate in } \\
\text { vocational and } \\
\text { technical high school }\end{array}$ \\
\hline Marmara & 92.4 & 88.1 & 9.95 & 115.7 & 41.1 & 29.4 \\
Central Anatolia & 90.3 & 85.0 & 10.31 & 93.0 & 41.6 & 21.7 \\
Aegean & 89.8 & 84.2 & 8.42 & 100.1 & 39.7 & 25.4 \\
Mediterranean & 88.2 & 82.0 & 8.28 & 97.7 & 42.2 & 16.6 \\
Blacksea & 85.8 & 78.5 & 5.92 & 87.4 & 31.7 & 23.0 \\
East Anatolia & 77.7 & 65.9 & 6.13 & 86.4 & 26.3 & 9.3 \\
Southeast Anatolia & 73.2 & 60.2 & 4.99 & 94.1 & 27.3 & 6.6 \\
\hline
\end{tabular}

Source: Gül (2007, p. 183).

The literacy rate also varies considerably between regions. The literacy rate is 92.4 percent in the Marmara Region, where is the highest per capita income, while it is 77.7 percent in the Eastern Anatolia Region and falls 73.2 percent in the South Eastern Anatolia Region. As the literacy rate for women is 88.1 percent in the Marmara Region, it falls to 66 percent and 60 percent respectively in Eastern and South Eastern Anatolia regions (Saygll1, Cihan, \& Yavan, 2006).

Along with the common problems seen in Turkey, there are also special issues based on the regional basis. Southeastern Anatolia Region is at the forefront of Turkey's most underdeveloped places in education. The main reasons are ecomonic status, culture, ethnicity, spoken languages (Şahin \& Gülmez, 1999; Gül, 2008). Among the special problems of Southeastern Anatolia, terror issues, education of girls (Şahin \& Gülmez, 1999; Tunç, 2009) and the children who work as seasonal labor so they cannot go to the schools in last two months, these situations should be listed as the part of the problems.

Terrorism is one of the biggest factors in the formation of education problems in South East Turkey. The negative effects of terrorism on the education can be listed as follows; some of the teachers would not like to go to this region because it becomes hardship area and some is unexperienced and newly arrival teachers. Many students have financial difficulties because terrorism affects the economical development and the education can be shown as assimilation in the region (B.A.A.K., 1997).

One of the educational problems of Southeastern Anatolia is the participation rate of girls to the education. 1739 National Education Law in Article 4, even though one paragraph says that "Educational institutions are open to everyone regardless of language, race, sex and religion", there are differences about the participation of girls and boys in the education system. There are many reasons why girls do not participate in education and here are the some reasons: economic inadequancies, cultural structure and understanding of men come first (Tunç, 2009). In order to reduce this difference especially in Eastern and Southeastern Anatolia, some campaigns are performed under the name of "Haydi Kizlar Okula" (Let Girls Go to School). Thanks to these campaigns, the participation of girls in education is increased, however the desired level is still not being reached. 


\subsection{The Purpose of This Study}

The purpose of this study is to identify the current problems of the teachers working in the provinces of Southeastern Anatolia and to list these problems according to their importance. Furthermore; this study helps others to understand the education problems and the teachers' problems in this region. In this context, it is sought to answer of the following questions:

1) Related to the education system, what are the current problems of teachers working in the Southeastern Anatolian provinces?

2) Is there a significant difference between the categories obtained from the problems expressed by the teachers?

3) Is there a significant difference between teachers' primary education problems and their gender?

4) Is there a significant difference between teachers' primary education problems and being in-field or classroom teacher?

5) Is there a significant difference between teachers' primary education issues and their seniority?

\subsection{The Importance of Research}

Education becomes a very important and functional tool in order to be richer and more prosperous country in the twenty-first century for the development efforts. Mean of education is to come fruition in long-term and at that point, as a tool that prepares human force which contributes the social and economic development of country, education becomes the main investment of the economy. In Turkey, education, science and technology production are needed to pay more attention than ever. In briefly, the importance of education is vital because education provides individual development and scientific, economic, social and cultural improvements; in addition the value of education should be perceived very well (Bowen, 1980). Education is one of the most important elements that increase the level of development of the society. The problems that arise in the education system hinder the progress and development of the society. The Turkish education system, the regional differences of the Turkish education system and the major educational problems was addressed in this study. Moreover, this study tried to address the problems of the Southeast region of Turkey. Southeastern Anatolia Region is one of the most problematic regions in Turkey in terms of education (Gül, 2008). The results of this study attempted to reveal the causes of this problem in terms of teacher opinions. The results of this study may be a guide for future solutions to the regional problems.

\section{Method}

This study was prepared in accordance with screening model which aims to describe teachers' current problems related to education system. In screening model, it is important to observe concordantly the described situation (Karasar, 2005). The collected data were analyzed using qualitative research method.

\subsection{Study Group}

The study group of this research constituted 270 teachers working in Gaziantep, Şanliurfa, Diyarbakır, Kahramanmaraş, Mardin, Şırnak and Adıyaman (Southeastern provinces). The specialties (class-in-field) of these teachers are given in Table 2. Purposeful sampling method was used to select the study group. Master students who worked in that cities as teachers collected the data from the study group working with them in the same school.

Table 2. Dispersion of teachers according to their specialties

\begin{tabular}{lll}
\hline Branch & Number of people & Percentage \% \\
\hline Class Teacher & 146 & 54 \\
In-field Teacher & 124 & 46 \\
\hline
\end{tabular}

Dispersion of teachers according to their gender is given in Table 3. 
Table 3. Dispersion of teachers according to their gender

\begin{tabular}{lll}
\hline Gender & Number of People & Percentage \% \\
\hline Female & 113 & 41.8 \\
Male & 157 & 58.2 \\
\hline
\end{tabular}

Dispersion of teachers according to their seniority is given in Table 4 .

Table 4. Dispersion of teachers according to their seniority

\begin{tabular}{lll}
\hline Seniority & Number of People & Percentage \% \\
\hline $\mathbf{1 - 3}$ year & 57 & 21.1 \\
$\mathbf{4 - 5}$ year & 25 & 9.2 \\
$\mathbf{6 - 7}$ year & 47 & 17.4 \\
$\mathbf{8 - 9}$ year & 38 & 14 \\
$\mathbf{1 0}$ and over & 103 & 38.3 \\
\hline
\end{tabular}

\subsection{Collecting Data}

In this study, teachers were asked to identify seven problems related to the education system and order them according to their importance. The seven open-ended questions were creted according to literature review and the final shape of the questions were taken with the comment of the academician specialized in the area.

\subsection{Analysis of Data}

The categories, relating to the problems expressed by the teachers, were determined. Descriptive analysis (frequency, percentage) were applied for these categories. The questions asked for the interviews were used to create the categories.

A chi-square analysis was conducted to determine whether there was a significant difference between the gender, seniority and class-branch.

\section{Findings}

The questions, answered according to the purpose of the study, are given as follows:

3.1 What Are the Current Problems of the Teachers Working in the Provinces in the Southeastern Anatolia Region Regarding the Education System?

A total of 39 different problems were identified by examining the data obtained from the teachers. According to similar features, these problems were gathered in six categories. These categories are given in Table 5.

Table 5. Education problems and frequencies

\begin{tabular}{|c|c|c|c|}
\hline \multicolumn{2}{|r|}{ Categories and Education Problems } & \multicolumn{2}{|c|}{ Frequency } \\
\hline & & Number & Percentage \\
\hline \multicolumn{2}{|r|}{ 1. Problems related with school's physical conditions } & 256 & 21.1 \\
\hline & 1.1. Equipment and physical inability at schools & 107 & 8.8 \\
\hline & 1.2. Crowded classes & 88 & 7.3 \\
\hline & 1.3. Inadequacy of lecture equipments & 27 & 2.2 \\
\hline & 1.4. Inadequacy of guidance service & 8 & 0.7 \\
\hline & 1.5. Inadequacy of technological possibility & 26 & 2.1 \\
\hline
\end{tabular}




\section{Problems related with teachers}

2.1. Discredit of teacher

2.2. Financial problems of teachers

2.3. Inadequacy of teacher and not adapt oneself

2.4. Not training the teachers well

2.5. Lack of the teacher motivation

2.6. Teacher field changes

3. Problems related to System

3.1. $4+4+4$ system problems

3.2. Continuous change of education system

3.3. The effect of political policies on education

3.4. Having a favor in education system

3.5. Having a mixed education system

3.6. Dual education system

4. Problems related to educational management, inspection, planning and economy

4.2. Centralized management and regulations (injustice)

4.3. Terminating the plow and discipline problems

4.4. 60 - 66 months old children going to school

4.5. Unnecessary paperwork, inappropriate practices

4.6. Inadequate school administration

4.7. NGOs not cooperating for Education

4.8. Financial problems of school

4.9. Inadequate inspection and evaluation

4.10. Lack of importance for pre-school education

5. Problems with Education Programs and training

5.1. Excessive course hours

5.2. Inadequate curriculum and textbooks

5.3. Lack of evaluation on in-service training

5.4. Projects and performances not reaching purpose

5.5. Education in the mother tongue and values education 

6.2. The low socio-economic status of parents
6.3. Dressing
6.4. Accusing teachers for students' fail
6.5. Lack of cooperation between parents and teacher

$\begin{array}{ll}26 & 2.1 \\ 28 & 2.3 \\ 11 & 0.9 \\ 36 & 3\end{array}$

The problems that teachers addressed in Table 5 are listed in six categories and these as follow: "the physical conditions of the school", "problems related to the teachers", "problems related to the system", "problems related to the education management, inspection, planning and economy", "problems related to the education programs and training", and "problems related to the students-parents". The following problems are included in the catagories as follows; $21.1 \%$ (256) of the problems, which indicated by teachers, are related to physical conditions of school, $22.1 \%$ (268) problems related to the teachers, $19.7 \%$ (239) problems related to the system, $16.2 \%$ problems related to the education management, inspection, planning and economy, $11.3 \%$ (137) problems related to the education programs and training and 9.6\% (117) problems related to the students-parents.

\subsection{Is There a Significant Difference between the Categories Obtained from the Problems That Are Addressed by} the Teachers?

A chi-square analysis was performed in order to determine whether there is a significant difference between the categories indicated in Table 5.

The results of this analysis are given in Table 6 .

Table 6. Chi-Square results

\begin{tabular}{lccc}
\hline & Value & Df & Asymp. Sig. (2-sided) \\
\hline Pearson Chi-Square & $8.120^{\mathrm{a}}$ & 5 & 0.150 \\
\hline
\end{tabular}

a. 0 cells $(0.0 \%)$ have expected frequencies less than 5 . The minimum expected cell frequency is 16.7 .

According to Table 6 , the chi-square value is $\chi^{2}(5)=8.120$. This value is not significant on $p=0.150(p>0.05)$ level. This result shows that there is no significant difference between the collected categories in which the problems were expressed by the teachers.

\subsection{Is There a Significant Difference between Teachers' Primary Education Problems and Their Gender?}

The first seven problems, that teachers most frequently addressed, are given in the table below according to the male and female numbers.

Table 7. Dispersion of first seven most frequently mentioned education problems by gender

\begin{tabular}{clll}
\hline Problems & Male & Female \\
\hline 1. & Equipment and physical inadequacy in schools & $65(\% 20.4)$ & $42(\% 20.2)$ \\
2. & Crowded classes & $51(\% 16)$ & $37(\% 17.8)$ \\
3. & Continuous change in education system & $48(\% 15)$ & $33(\% 15.9)$ \\
4. & Discredit of teacher & $50(\% 15.7)$ & $29(\% 13.9)$ \\
5. & Inadequacy of curriculum and textbooks & $35(\% 11)$ & $25(\% 12)$ \\
6. & Financial depression of teachers & $39(12.2)$ & $18(\% 8.7)$ \\
7. & Problems caused by 4+4+4 system & $31(9.7)$ & $24(\% 11.5)$ \\
Total & $319(\% 100)$ & $208(\% 100)$ \\
\hline
\end{tabular}

According to Table 7, the chi-square analysis was conducted in order to determine whether the first seven questions that teachers frequently expressed are significant or not from gender. The result of this analysis is given in the following Table 8 . 
Table 8. Chi-Square analysis results

\begin{tabular}{llll}
\hline & Value & df & Asymp. Sig. (2-sided) \\
\hline Pearson Chi-Square & $0.932^{\mathrm{a}}$ & 6 & 0.988 \\
Likelihood Ratio & 0.934 & 6 & 0.988 \\
Linear-by-Linear Association & 0.016 & 1 & 0.900 \\
\hline
\end{tabular}

a. 0 cells $(0.0 \%)$ have expected count less than 5 . The minimum expected count is 10.45 .

According to Table 8 , the chi-square value is $\chi^{2}(6)=0.932$. This value is not significant on $p=0.988(p>0.05)$ level. This result shows that the first seven problems frequently expressed by the teachers do not represent a significant difference according to gender.

3.4 Is There a Significant Difference between Teachers' Primary Education Problems and Being Branch or Classroom Teacher?

The dispersion of the first seven problems most frequently expressed by teachers is given according to class-branch teacher in the table below.

Table 9. The dispersion of first seven problems frequently mentioned in education according to class-branch

\begin{tabular}{|c|c|c|c|}
\hline \multicolumn{2}{|c|}{ Problems } & \multirow{2}{*}{$\begin{array}{l}\text { Class } \\
67(\% 20.6)\end{array}$} & \multirow{2}{*}{$\begin{array}{l}\text { Branch } \\
40(\% 19.8)\end{array}$} \\
\hline 1. & Equipment and physical inadequacy in schools & & \\
\hline 2. & Crowded classes & $61(\% 18.8)$ & $27(\% 13.4)$ \\
\hline 3. & Continuous change in education system & $44(\% 13.5)$ & $37(\% 18.3)$ \\
\hline 4. & Discredit of teacher & $53(\% 16.3)$ & $26(\% 12.9)$ \\
\hline 5. & Inadequacy of curriculum and textbooks & $30(\% 9.2)$ & $30(\% 14.9)$ \\
\hline 6. & Financial depression of teachers & $40(\% 12.3)$ & $17(\% 8.4)$ \\
\hline 7. & Problems caused by $4+4+4$ system & $30(\% 9.2)$ & $25(\% 12.4)$ \\
\hline \multicolumn{2}{|c|}{ Total } & $325(\% 100)$ & $202(\% 100)$ \\
\hline
\end{tabular}

According to Table 9, the chi-square analysis was conducted in order to determine whether the first seven questions that teachers frequently expressed are significantly different from class-branch or not. The result of this analysis is given in the following table.

Table 10. Chi-Square analysis results

\begin{tabular}{llll}
\hline & Value & df & Asymp. Sig. (2-sided) \\
\hline Pearson Chi-Square & $4.683^{\mathrm{a}}$ & 6 & 0.585 \\
Likelihood Ratio & 4.715 & 6 & 0.581 \\
Linear-by-Linear Association & 0.393 & 1 & 0.531 \\
N of Valid Cases & 199 & & \\
\hline
\end{tabular}

a. 0 cells $(0.0 \%)$ have expected count less than 5 . The minimum expected count is 9.95 .

According to Table 10 , the chi-square value is $\chi^{2}(6)=4.683$. This value is not significant on $p=0.585(p>0.05)$ level. This result shows that the first seven problems that teachers often express, are not significantly different from class-branch. 


\subsection{Is There a Significant Difference between Teachers' Primary Education Problems and Their Seniority?}

The dissociation of first seven problems frequently expressed by teachers is given in the table below in accordance with the seniority of teachers.

Table 11. The dispersion of first seven problems that frequently mentioned in education according to seniority

\begin{tabular}{|c|c|c|c|c|c|c|}
\hline \multicolumn{2}{|c|}{ Problems } & \multirow{2}{*}{$\begin{array}{l}\text { 1-3 year } \\
24\end{array}$} & \multirow{2}{*}{$\begin{array}{l}\text { 4-5 years } \\
9\end{array}$} & \multirow{2}{*}{$\begin{array}{l}\text { 6-7 years } \\
20\end{array}$} & \multirow{2}{*}{$\begin{array}{l}\text { 8-9 years } \\
12\end{array}$} & \multirow{2}{*}{$\begin{array}{l}10 \text { years and over } \\
42\end{array}$} \\
\hline 1. & Equipment and physical inadequacy in schools & & & & & \\
\hline & & $\% 20.9$ & $\% 20.5$ & $\% 19$ & $\% 20.3$ & $\% 20.6$ \\
\hline \multirow[t]{2}{*}{2.} & Crowded classes & 20 & 6 & 15 & 11 & 36 \\
\hline & & $\% 17.4$ & $\% 13.6$ & $\% 14.3$ & $\% 18.6$ & $\% 17.6$ \\
\hline \multirow[t]{2}{*}{3.} & Continuous change in education system & 14 & 5 & 13 & 8 & 41 \\
\hline & & $\% 12.2$ & $\% 11.4$ & $\% 12.4$ & $\% 13.6$ & $\% 20.1$ \\
\hline \multirow[t]{2}{*}{4.} & Discredit of teacher & 12 & 9 & 20 & 10 & 28 \\
\hline & & $\% 10.4$ & $\% 20.5$ & $\% 19$ & $\% 16.9$ & $\% 13.7$ \\
\hline \multirow[t]{2}{*}{5.} & Inadequacy of curriculum and textbooks & 25 & 6 & 12 & 5 & 12 \\
\hline & & $\% 21.7$ & $\% 13.6$ & $\% 11.4$ & $\% 8.5$ & $\% 5.9$ \\
\hline \multirow[t]{2}{*}{6.} & Financial depression of teachers & 9 & 4 & 12 & 7 & 25 \\
\hline & & $\% 7.8$ & $\% 9.1$ & $\% 11.4$ & $\% 11.9$ & $\% 12.3$ \\
\hline \multirow[t]{2}{*}{7.} & Problems caused by $4+4+4$ system & 11 & 5 & 13 & 6 & 20 \\
\hline & & $\% 9.6$ & $\% 11.4$ & $\% 12.4$ & $\% 10.2$ & $\% 9.8$ \\
\hline \multirow{2}{*}{\multicolumn{2}{|c|}{ Total }} & 115 & 44 & 105 & 59 & 204 \\
\hline & & $\% 100$ & $\% 100$ & $\% 100$ & $\% 100$ & $\% 100$ \\
\hline
\end{tabular}

According to Table 11, the chi-square analysis was conducted in order to determine whether the first seven questions that teachers frequently expressed are significantly different from teachers' seniority or not. The result of this analysis is given in the following table.

Table 12. Chi-Square analysis results

\begin{tabular}{llll}
\hline & Value & df & Asymp. Sig. (2-sided) \\
\hline Pearson Chi-Square & $23.394^{\mathrm{a}}$ & 24 & 0.497 \\
Likelihood Ratio & 22.913 & 24 & 0.525 \\
Linear-by-Linear Association & 0.561 & 1 & 0.454 \\
N of Valid Cases & 501 & & \\
\hline
\end{tabular}

a. 0 cells $(0.0 \%)$ have expected count less than 5 . The minimum expected count is 10.17 .

According to Table 12, the chi-square value is $\chi^{2}(24)=23.394$. This value is not significant on $p=0.497(\mathrm{p}>$ 0.05) level. This result shows that the first seven problems that teachers often expressed are not significantly different from teachers' seniority.

\section{Results and Discussion}

In the study from the obtained data, a total of 39 problems were identified under six categories. These problems are listed under the these six categories: 1) Physical conditions of the school, 2) Problems with the teacher, 3) Problem with the system, 4) Education management, inspection, planning and economy, 5) Curriculum and instruction, 6) Problems with the student. Many of these problems support and being parallel with the results of previous studies 
(Aşkar, 2007; Arslan, 2004; Balc1, 2004; Gül, 2008; Karadeniz, 2012; Tunç, 2009). There was no significant difference among these problems according to categorical, sex, class-branch teaching, and seniority.

Teachers are the educations' indispensable and most important part. The views of the teachers on educational problems have been talked for years. It is frequently mentioned in the National Education Program and Scientific Congresses, even non-governmental organizations related to education share the problems related to the issue publicly. When researches examined educational problems based on teachers' opinion in the past years, it was found that the problems did not differ much from today's problems. It was found that the main problems are the teacher training, their employment and the personal rights (Doğan, 2005; Şahin, 2011). Similar problems are noteworthy in this research, which deals with the regional problems rather than the general problems of the teachers in Turkey.

Teachers working in the Southeastern Anatolia Region expressed the problems relating to the teaching profession as the most important context of educational problems. In this research; it is pointed out that the teaching profession become increasingly discredited, teachers have financial difficulties, they cannot develop themselves with their professional inadequacies, the universities do not train good teachers, there are no motivational elements for teachers and lastly that teachers' field changes are among the main problems in terms of education. These problems are not limited to only the Southeastern Anatolia Region but similar problems can be seen in other regions of Turkey as well (Aydın, 2009; Seferoğlu, 2001; Ocak et al., 2005).

In this study, it is seen that the second important problem that teachers addressed about educational problems is "relating to school physical conditions". Physical inadequacy in schools, inadequacy of the technological equipments in the schools, crowded classes, lack of course tools and equipment are common problems in our country as a whole. According to Yilmaz (2007), the problems of the science teachers are listed as follows: lack of tools and equipment, crowded classes, lack of equipped laboratories. Yapıc1 and Yapıcı (2001) stated that infrastructure problems in education (technological equipment, lack of equipment, modern buildings, etc.) still continue.

Teachers' discomfort against frequent change of the education system due to the specified political concerns. The teacher said that the $4+4+4$ education system which is put into practice without any infrastructure brings several problems to the teachers. The fact that the education system is always based on the examination is also seen as a very important problem for the teachers. With these changes in education programs, teachers emphasize the problems such as bureaucratic procedures (primary school standards, guard duties, celebrations, etc.), large number of students, and inadequate physical conditions and limited social opportunities in schools (Demir \& Ar1, 2013) as their second and third primary problems. In addition, because of the application of double shift schooling in large number of schools, It is thought to cause a decrease in the productivity of students and teachers.

Teachers regarding management, inspection and planning are as their third problem in the list. Absence of any sanctioning authority for teachers on disciplinary issues in schools and the neglect of the classes due to the skipping of the class negatively affects the motivation of the teachers. It can be said that this situation is also the basis of increasing disciplinary acts in Turkey in recent times. Due to the lack of financial resources in schools, various activities (theater, conferences, etc.) which are thought to make the school attractive, can not be realized. This can also be said to monotonize the school.

Teachers, who say that the educational programs are very intense and the gains are too much, think that the lesson hours are also quite long. According to the teachers who think that the textbooks are lack of information point, the changes and developments in education should bring along the updates in the in-service training at the same time. Teachers who regard in-service training think that this training is not as competent and as necessary as it should be. Bumen and her friends (2012) pointed out that the research and publications related to professional development of teachers in Turkey should be increased in terms of quality and quantity and the name of the Ministry of National Education. In-service Training Department should also be changed.

When the opinions of the teachers in the Southeast working on the problems of the education system are examined, it is observed that similar problems are experienced in other regions in Turkey where the problem is not localized (Gül, 2008). Teachers ratio who brings up the subject of education in mother tongue that is thought to be regional problem arised from the ethnic origin in the region, is only $1.8 \%$. In fact, this rate is expected to be higher, but it is now seen that when the new generation starts going to shcool with communication instruments and by this way they already start learning Turkish through other communication tools such as television or computer. 
Recently, with the political developments in our country, the problem of terrorism decreases in great proportions and the rights granted to the people of the region through democratization packages have provided economic recovery with eastern oriented incentive funds (Avrupa Komisyonu, 2012). Owing to university openings in every city in the region, local community overcomes the prejudices about schools. This situation helps to increase participation of girls into education.

There are some positive changes which abolish the inequalities between the regions. These changes can be listed such as; the media in Turkey does not recently bring forward negative news about the Southeast region, increasing of the welfare level of people due to recent improvements, environment of trust and speed in both roadway and airway, offering different alternatives in every single cities to young teachers who come here (cinema, cafe, exhibition etc.). Therefore, it can be said that the education participation rate of the girls, which is thought to draw attention as a problem on the regional basis, and which are rarely mentioned in the media, and the problem of education in the mother tongue was only raised by few teachers, are related to recent developments. Investigators can examine that how these developments contribute to the education in Southeast.

\section{References}

Akyüz, Y. (2012). Türk eğitim tarihi, M. Ö. 1000-M.S. 2012. Ankara: Pegem Yayınları.

Arslan, M. (2004). Eğitim sistemimizin kapanmayan yarası yükseköğretime geçiş. Erciyes Üniversitesi Sosyal Bilimler Dergisi, 16(1), 37-51. Retrieved from http://dergipark.gov.tr/erusosbilder/issue/23749/253025

Aşkar, P. (2007). İlköğretim programlarının ve uygulamalarının değerlendirilmesi. In S. Özdemir, H. Bacanlı, \& M. Sözer (Eds.), Türkiye'de okul öncesi eğitim ve ilköğretim sistemi: Temel sorunlar ve çözüm önerileri (pp. 186-210). Ankara: Türk Eğitim Derneği Yayınları.

Avrupa Komisyonu. (2012). Türkiye 2011 yılı ilerleme raporu. Avrupa Birligi Bakanligi (Çev). Retrieved February 27, 2017, from http://www.ab.gov.tr/files/ceb/Progress_Reports/2012_ilerleme_raporu.pdf

Aydın, R. (2009). Türkiye'de öğretmen sorunları açısından milli eğitim şûralarının değerlendirilmesi (1980-2000). Ankara Üniversitesi Eğitim Bilimleri Dergisi, 42(2), 199-237.

Aykaç, N., Kabaran, H., Atar, E., \& Bilgin, H. (2014). Turkish studies-international periodical for the languages. Literature and History of Turkish or Turkic, 9(2), 335-348.

B.A.A.K (Başbakanlık Aile Araştırma Kurumu). (1998). Doğu ve Güneydoğu Anadolu'dan terör nedeniyle göç eden ailelerin sorunları. In Bilim Serisi. Ankara. Retrieved from http://ailetoplum.aile.gov.tr/data/54293ea2369dc32358ee2b25/kutuphane_35_dogu_ve_guneydogu_anado lu__dan_teror_nedeniyle_goc_eden_ailelerin_sorunlari_.pdf

Balc1, A. (2004). Türkiye'de eğitim yöneticisi ve eğitim müfettişi yetiştirme uygulamaları: Sorunlar ve öneriler. Çă̆daş Ĕ̈itim, 29(307), 22-40.

Bowen, B. E. (1980). Job satisfaction of teacher educators in agriculture (Doctoral dissertation). Ohio State University. Retrieved from https://etd.ohiolink.edu/rws_etd/document/get/osu1240486019/inline

Bümen, N. T., Ateş, A., Çakar, E., Ural, G., \& Acar, V. (2012). Türkiye bağlamında öğretmenlerin mesleki gelişimi: Sorunlar ve öneriler. National Education, 194, 31-50. Retrieved from http://www.academia.edu/download/20652704/194.pdf\#page=32

Çalık, T., Türker, K. U. R. T., \& Çalık, C. (2011). Güvenli okulun oluşturulmasında okul iklimi: Kavramsal bir çözümleme. Pegem Ĕ̈itim ve Öğretim Dergisi, 1(4), 73-84. Retrieved from http://www.pegegog.net/index.php/pegegog/article/viewFile/C1S4M8/C1N4M8

Demir, M. K., \& Arı, E. (2013) Öğretmen sorunları-Çanakkale İli örneği. Ondokuz Mayıs Üniversitesi Eğitim Fakültesi Dergisi, 32(1), 107-126. http://dergipark.ulakbim.gov.tr/omuefd/article/download/5000035644/5000034567

Demirezen, M. (2012). 4+4+4 Yasasının eğitimsel yapısı ve uygulanmasındaki olgular. 1. Yabancı Dil Egitimi Çalıstayı Bildirileri, 126-132.

DİE. (2000). Nüfus sayımı sonucları. Ankara, Turkey.

Doğan, C. (2005). Türkiyede sınıf öğretmeni yetiştirme politikaları ve sorunları. Bilig (Türk Dünyası Sosyal $\begin{array}{lllll}\text { Bilimler Dergisi), } & \text { 35, } & \text { Retrieved } & \text { from }\end{array}$ http://www.acarindex.com/dosyalar/makale/acarindex-1423873380.pdf 
Eğitim Sen. (2009a). 2009-2010 eğitim-öğretim yll basinda ĕgitimin durumu. Retrieved from http://www.egitimsen.org.tr/down/230909_egitimrapor.pdf

Eraslan, A. (2009). Finlandiya'nın PISA'daki başarılarının nedenleri: Türkiye için alınacak dersler. Necatibey Eğitim Fakültesi Elektronik Fen ve Matematik Eğitimi Dergisi, 3(2), 238-248. Retrieved from http://dergipark.ulakbim.gov.tr/balikesirnef/article/viewFile/5000084781/5000078863

ERG. (2010). Ë̆itimde izleme raporu 2009. İstanbul: ERG.

ERG. (2012). Eğitimde izleme raporu 2011. İstanbul: ERG.

Fidan, F., \& Fidecioğlu, A. (2010). Kutsallıkla tutsallık arasında bir meslek öğretmenlik: Sorunlar, yaklaşımlar ve beklentiler. Adlyaman Üniversitesi Sosyal Bilimler Enstitüsü Dergisi, 3(5), 146-160. Retrieved from http://dergipark.ulakbim.gov.tr/adyusbd/article/viewFile/5000041789/5000039317

Gedikoğlu, T. (2005). Avrupa birliği sürecinde Türk eğitim sistemi: Sorunlar ve çözüm önerileri. Mersin Üniversitesi Eğitim Fakültesi Dergisi, 1(1), 66-80.

Gül, H. (2007). Türkiye'de eğitimde finans sorunu ve nedenleri. In S. Sallan Gül, \& H. Gül (Eds.), Eğitimde reform ve finans sorunu sempozyumu bildiriler kitabı (pp. 183-199). Süleyman Demirel Üniversitesi Yayınları, Isparta.

Gül, H. (2008). Türkiye'nin eğitim sorunları, AKP'nin eğitime bakışı ve çözüm önerileri. Toplum ve Demokrasi, 2(3), 181-196. Retrieved from http://dergipark.gov.tr/download/article-file/211021

Gülbahar, Y., \& Güven, İ. (2008). A survey on ICT usage and the perceptions of social studies teachers in Turkey. Educational Technology \& Society, 11(3), 37-51. Retrieved from http://www.ifets.info/journals/11_3/4.pdf

Karadeniz, C. B. (2012). Öğretmenlerin 4+4+4 zorunlu eğitim sistemine ilişkin görüşleri. Eğitim Bilim Toplum Dergisi, 10(40), 34-53. $\quad$ Retrieved from http://egitimbilimtoplum.com.tr/index.php/ebt/article/viewFile/488/pdf?skbzrsrpcvxbmfbt

Küçükahmet, L. (1999). Öğretmenlik mesleğine giriş. İstanbul: Alkım Yayınevi.

Meb Mevzuat. (1973). 1739 sayll milli eğitim kanunun 4. maddesi. Retrieved from http://mevzuat.meb.gov.tr

MEB. (2005). Pilot iller iletişim bileşeni başlangıç araştırması. Avrupa birliği-Türkiye temel eğitime destek projesi. Ankara: MEB.

MEB. (2009). Milli Ĕ̆itim Bakanlığı 2010-2014 stratejik plani. Ankara: Strateji Geliştirme Başkanlığı.

MEB. (2010). On sekizinci Millı̂ Eğitim Şûrası. Ankara: MEB.

Ocak, G., Gündüz, M., Özdemir, A. M., \& Kaya, Ü. (2005). Öğretmenlerde sosyal statü sorunları (Afyonkarahisar il örneği). In XIV. Ulusal Eğitim Bilimleri Kongresi (pp. 28-30).

Şahin, İ. (2011). Öğretmen adaylarının öğretmen istihdamı ve mesleki geleceklerine ilişkin görüşleri. Kuram ve Uygulamada Eğitim Bilimleri, 11(3), 1167-1184. Retrieved from https://www.researchgate.net/profile/Idris_Sahin3/publication/281612669_Ogretmen_Adaylarinin_Ogretme n_Istihdami_ve_Mesleki_Geleceklerine_Iliskin_Gorusleri/links/55efe06a008aedecb68fdcef3.pdf

Şahin, İ., \& Gülmez, Y. (1999). Social sources of failure in education: The case in East and Southeast Turkey. Social Indicators Research, 49, 83-113. https://doi.org/10.1023/A:1007058421749

Saygıll, Ş., Cihan, C., \& Yavan, Z. A. (2006). Eğitim ve sürdürülebilir büyüme Türkiye deneyimi, riskler ve firsatlar. İstanbul: TÜSİAD Yayınları.

Seferoğlu, S. S. (2001). Sınıf öğretmenlerinin kendi meslekî gelişimleriyle ilgili görüşleri: Beklentileri ve önerileri. Millì Eğitim Dergisi, 149, 12-18.

SETA. (2014). 2013 'te eğitim çallşstayı. Retrieved from http://setav.org/tr/2013te-egitim-calistayi/haber/14331

Tunç, A. İ. (2009). Kız çocuklarinin okula gitmeme nedenleri Van ili örneği. Yüzüncü Yll Üniversitesi, Eğitim $\begin{array}{lllll}\text { Fakültesi } & \text { Dergisi, } & 6(1), & \text { 237-269. } & \text { Retrieved }\end{array}$ http://efdergi.yyu.edu.tr/eskiefdergi/makaleler/cilt_VI/haziran/a_i_tunc.pdf

Yaman, E. (2006). Eğitim sistemindeki sorunlardan bir boyut: Büyük sınıflar ve sınıf yönetimi. Gazi Üniversitesi Türk Eğitim Bilimleri Dergisi, 4(3), 261-274. Retrieved from http://www.tebd.gazi.edu.tr/index.php/tebd/article/viewFile/52/43 
Yaman, E. (2010). Kalabalık sınıfların etkileri: Öğrenciler ne düşünüyor? Kastamonu Eğitim Dergisi, 18(2), 403-414. Retrieved from http://www.kefdergi.com/pdf/18_2/18_2_6.pdf

Yapıc1, M., \& Yapıcı, Ş. (2001). İlköğretim öğretmenlerinin karşıllaştı̆̆ı sorunlar. Üniversite ve Toplum, 3(3), 9-12. Retrieved from http://www.universite-toplum.org/text.php3?id=142r7

Yılmaz, G. (2007). Sinıf öğretmeni adaylarının ögretmenlik uygulaması deneyimlerinin fen ögrretimi öz yeterlik ve sinıf yönetimi inançlarına olan etkisi (Doctoral dissertation). Ege Üniversitesi. Retrieved from http://acikerisim.ege.edu.tr:8081/xmlui/bitstream/handle/11454/2676/gokceyilmaz2007.pdf?sequence=1\&is Allowed $=\mathrm{y}$

YKKED. (2007). Özgürlük ve demokrasi için kapsamlı bir eğitim reformu acildir: Yeni Kuşak Köy Enstitülüler Derneği'nin 2007-2008 Eğitim Öğretim Yılı'na İlişkin asın Açıklaması. Yeniden İmece, 4(16).

Yolcu, H., \& Kartal, S. (2010). Eğitim fakültesi son sınıf öğrencilerinin görüşlerine göre Türkiye eğitim sistemine ilişkin yaşanılan sorunlar. In Ulusal Sinıf Öğretmenliği Eğitimi Sempozyumu (pp. 478-483).

\section{Copyrights}

Copyright for this article is retained by the author(s), with first publication rights granted to the journal.

This is an open-access article distributed under the terms and conditions of the Creative Commons Attribution license (http://creativecommons.org/licenses/by/4.0/). 